\title{
The Stability of Monetary Unions: Lessons from the Breakup of Czechoslovakia ${ }^{1}$
}

\author{
Jan Fidrmuc,* Julius Horvath, $\dagger$ and Jarko Fidrmuc $\ddagger$
}

*Center for European Integration Studies (ZEI), University of Bonn, Walter-Flex-Strasse 3, 53113 Bonn, Germany; and Center for Economic Research, Tilburg University, Netherlands; $\dagger$ Academia Istropolitana Nova, Bratislava, Slovakia; Central European University, Nador u. 9, 1051 Budapest 5, Hungary; and Center for European Integration Studies (ZEI), University of Bonn, Bonn, Germany; and $\ddagger$ Institute for Advanced Studies (IHS), Stumpergasse 56, 1060 Vienna, Austria

E-mail: Fidrmuc@united.econ.uni-bonn.de,Horvath_julius@mail.matav.hu,Fidrmuc@ihs.ac.at Received July 1, 1998; revised August 16, 1999

Fidrmuc, Jan, Horvath, Julius, and Fidrmuc, Jarko-The Stability of Monetary Unions: Lessons from the Breakup of Czechoslovakia

In 1993, Czechoslovakia experienced a two-step breakup. On January 1, the country disintegrated as a political union, while preserving an economic and monetary union. Then, the Czech-Slovak monetary union collapsed on February 8. This paper analyzes the economic background of the two breakups from the perspective of the optimum currency area literature. The main finding is that the Czech and Slovak economies were vulnerable to asymmetric economic shocks, such as those induced by the economic transition. In particular, the stability of Czechoslovakia was undermined by the low correlation of permanent output shocks, low labor mobility, and higher concentration of heavy and military industries in Slovakia. J. Comp. Econ., December 1999, 27(4), pp. 753-781. Center for European Integration Studies (ZEI), University of Bonn, Walter-Flex-Strasse 3, 53113 Bonn, Germany, and Center for Economic Research, Tilburg University, Netherlands; Academia Istropolitana Nova, Bratislava, Slovakia, Central European University, Nador u. 9, 1051 Budapest, Hungary, and Center for European Integration Studies (ZEI), University of Bonn, Bonn, Germany; Institute for Advanced Studies (IHS), Stumpergasse 56, 1060 Vienna, Austria. (C) 1999 Academic Press

${ }^{1}$ We received helpful comments and suggestions from Beatriz de Blas, John P. Bonin, Tom Coupe, Thomas J. Courchene, Jana Fidrmucova, Richard Grabowski, Jürgen von Hagen, Marco Hoeberichts, Abdul Noury, Gérard Roland, Harald Uhlig, Warren E. Weber, Oved Yosha, two anonymous referees, seminar participants at the ZEI Summer School and ECARE, as well as from participants in the European Economic Association conference in Berlin. Jan Fidrmuc acknowledges support from the European Union's Phare ACE Program 1996 and the Netherlands Organization for Scientific Research. 
Key Words: optimum currency areas; disintegration; Czechoslovakia.

Journal of Economic Literature Classification Numbers: F33, F36, F42.

\section{INTRODUCTION}

In 1993, Czechoslovakia ${ }^{2}$ experienced a two-step breakup. On January 1, the political union of the Czech and Slovak republics disintegrated, while an economic and monetary union was preserved. On February 8, the Czech-Slovak monetary union collapsed. In this paper, we analyze the two breakups and attempt to draw implications for the stability of monetary unions. Our main aim is not to explain the failure of Czechoslovakia as a political union. Rather, we focus on the economic reasons underlying the collapse of the Czech-Slovak monetary union.

The disintegration of Czechoslovakia is most often explained by the political deadlock following the 1992 general election; see, for example, Batt (1993), Wolchik (1995), and Stranger (1996). Economic factors are considered to have played only a minor role in causing the breakup. Dedek et al. (1996) describe the economic background of the breakup and emphasize that the two economies converged rather than diverged, at least after the second world war. They see political motives as the culprits behind the breakup. Capek and Sazama (1993) and Pavlinek (1995) blame the differences in attitudes toward economic reform for the breakup. On the one hand, the Czechs associated socialism with stagnation and/or deterioration of their standard of living. On the other hand, the Slovaks saw socialism as a period of rapid growth and of catching up with the richer Czech Lands. As a result, these authors argue, there was much stronger resistance toward economic reforms in Slovakia than in the Czech Republic. ${ }^{3}$ However, while this explanation of differences in support for reforms is quite plausible, Jan Fidrmuc (1999a) links electoral support for reforms to the costs and benefits of the reforms. In particular, higher unemployment and lower entrepreneurial activity in Slovakia made the reforms less popular there compared to in the Czech Republic.

Although the economic factors of the breakup of Czechoslovakia, and subsequently the Czech-Slovak monetary union, have not received much attention in the literature, we believe there are important lessons to be learned from the breakup, particularly regarding the stability of other monetary arrangements. Our approach is based on the theory of optimum currency areas (OCA), initiated by

${ }^{2}$ Korbel (1977) presents the modern history of Czechoslovakia from its creation in 1918. Dedek et al. (1996) describe the decline of the federation and its demise in 1992.

${ }^{3}$ These differences in public attitudes found their reflection also in opinion surveys. In one such survey conducted in 1991 (Rose, 1992), 58\% of Slovak respondents expressed preference for a controlled economy, compared with $31 \%$ in support of a free-market economy. In the Czech Republic, on the other hand, 54\% said they preferred a free-market economy, while 35\% preferred a controlled economy. In both republics, $11 \%$ answered "don't know." 
the seminal contribution of Mundell (1961), which was followed by McKinnon (1963) and Kenen (1969). The basic idea of OCA theory is that only countries or regions exposed to symmetric shocks, or possessing the mechanisms for absorption of asymmetric shocks, will find it optimal to adopt a common currency. Therefore, this literature focuses on assessing the symmetry of output shocks in monetary unions ${ }^{4}$ and/or evaluating the absorption mechanisms such as labor mobility or fiscal transfers. The literature also recognizes the crucial role of political factors for creating and sustaining monetary unions; see, for example, Goodhart (1995). As Machlup (1977, p. 71) put it, "an optimum currency area is a region no part of which insists on creating money and having a monetary policy of its own."

Empirical literature on disintegration, however, is scarce. Dornbusch (1992), Garber and Spencer (1994), and Cheikbossian (1995) look at the breakup of the Austro-Hungarian Empire and draw lessons for the then ongoing breakup of the Soviet Empire and currency reforms. Cohen (1993) looks at the sustainability of monetary unions based on a comparative analysis of six historical examples of monetary integration. ${ }^{5}$ He discusses economic, organizational, and political factors, and identifies the last group as those most instrumental for the sustainability of monetary cooperation among sovereign governments.

In the present paper, we analyze the economic background of the two-step Czechoslovak breakup and draw implications for the stability of monetary unions. Our aim is to identify what economic factors contributed to the failure of the Czech-Slovak Monetary Union. If the disintegration of Czechoslovakia was indeed caused solely by political factors, then there was little rationale for abandoning the common currency. The political objectives of the two nations could have been realized while the monetary union was retained. The fact that a common currency did not last for more than five weeks suggests that there may have been deeper economic reasons for the breakup.

In Section 2, we describe the events leading up to and accompanying the two-step breakup of Czechoslovakia and the Czech-Slovak Monetary Union. In Section 3, we start by discussing briefly the implications of OCA theory for the stability of integration, and we then apply the criteria of the OCA literature to identify economic factors underlying the breakup of Czechoslovakia. In Section 4 , we discuss the benefits and costs brought about by the breakup to the successor

\footnotetext{
${ }^{4}$ The importance of output shocks is also emphasized by Jan Fidrmuc (1999b), who explores the incentives for (dis)integration in a political economy model of a union with centralized fiscal policy. He argues that the stability of integration depends not only on the correlation, or symmetry, of shocks but also on their persistence.

${ }^{5}$ The examples are Belgium-Luxembourg Economic Union, CFA Franc Zone, East Caribbean Currency Area, East African Community, Latin Monetary Union, and Scandinavian Monetary Union.
} 
countries. Finally, in the last section, we derive some conclusions for other monetary unions.

\section{THE TWO-STEP BREAKUP OF CZECHOSLOVAKIA}

The split of Czechoslovakia occurred as a consequence of the parliamentary election in June 1992. In the Czech Republic, a coalition of three right-of-center parties won, whereas a left-wing nationalist party won in Slovakia. Soon it became clear that the two sides were unable, or unwilling, to form a federal government together. The main points of conflict were the redistribution of power between the federation and the constituent republics ${ }^{6}$ and the design of further reforms. Eventually, the Czechs and Slovaks agreed to disagree by deciding to dismantle the federation and create two independent countries as of January 1, 1993, only half a year after the elections.

To mitigate the economic effects of the split, the Czech Republic and Slovakia retained the common currency, the customs union, and the common labor market. While the customs union and the free movement of labor were intended to remain in place indefinitely, the monetary union was conceived to be a temporary measure. Nevertheless, the two sides agreed to retain it at least for the first six months of 1993 and then consider further extensions. However, each side could withdraw from the union in any of the following situations: (1) a fiscal deficit of either republic exceeding $10 \%$ of budget revenues; (2) foreign exchange reserves of either republic falling below one month's worth of its imports; (3) interrepublic capital transfers exceeding $5 \%$ of total bank deposits; and (4) the Monetary Committee being unable to reach an agreement on fundamental monetary-policy issues.

The State Bank of Czechoslovakia (SBCS) ceased to exist with the demise of the federation, and instead both republics established their own central banks. A Monetary Committee was designed and charged with determining a common monetary policy. The governors as well as two senior officials from each central bank were members of this committee. Monetary policy was decided by simple majority vote. The policies were to be implemented jointly by both central banks.

However, it soon became clear that the ensuing monetary union would not enjoy much credibility. Foreign exchange reserves declined substantially in November and December 1992 and continued to decline throughout January 1993. Lack of credibility was also evident in the evolution of the parallel exchange rate of the Czechoslovak koruna (CSK), i.e., the exchange rate quoted by foreign commercial banks. According to Prokop (1994, p. 46), the parallel rate

\footnotetext{
${ }^{6}$ The emphasis on this objective reflected the widely accepted belief in Slovakia that its position within the federation was unequal to that of the Czech Republic. According to a survey reported by Rose (1992), 63\% of the Slovak respondents believed that the system of government was fair to the Czechs, but only $20 \%$ believed it was fair to the Slovaks. In contrast, $61 \%$ of the Czech respondents believed the system was fair to them, and $57 \%$ believed it was fair to the Slovaks.
} 
climbed to 51.56 CSK per dollar or $78 \%$ more than the official exchange rate. Moreover, foreign banks ceased trading in the CSK around mid-January 1993, and did not start trading in the successor currencies until March 1993.

During late 1992 and throughout January 1993, many Slovak residents and firms transferred funds to Czech commercial banks in expectation of a Slovak devaluation shortly after the split. Further, Czech exports to Slovakia shot up substantially toward the end of 1992. Moreover, in expectation of future devaluation of the Slovak currency, Slovak importers sought to repay their debts as soon as possible while the Czech importers did exactly the opposite (Prokop, 1994; Smidkova, 1994). These developments led to a gradual outflow of currency from Slovakia into the Czech Republic. The SBCS, and later the CNB, attempted to balance this outflow by credits to Slovak banks, but this became increasingly difficult in December 1992 and January 1993. Therefore, the Czech government and the CNB decided on January 19, 1993, to separate the currency (Prokop, 1994). After secret negotiations with the Slovak side, February 8, 1993 was set to be the separation date. Thus, the Czech-Slovak Monetary Union ceased to exist less than six weeks after the breakup of Czechoslovakia.

Monetary separation was announced publicly on February 2. Starting on February 3, all payments between the two republics stopped and border controls were increased to prevent transfers of cash from one country to the other. During the separation period between February 4 and 7, Thursday through Sunday, old Czechoslovak currency was exchanged for the new currencies. The new currencies became valid on February 8. Regular Czechoslovak banknotes were used temporarily in both republics and were distinguished by a paper stamp attached to the face of the banknote. The public was encouraged to deposit cash in bank accounts prior to the separation since a person could only exchange CSK 4,000 in cash. ${ }^{7}$ Business owners were not subjected to this limit.

Coins and small denomination notes (CSK 10, 20, and 50 in the Czech Republic and CSK 10 and 20 in Slovakia) were still used after the separation for several months. Nevertheless, such notes and coins only each accounted for some $3 \%$ of the currency in circulation. On the other hand, the notes of CSK 10, 20, and 50 accounted for some $45 \%$ of the total number of banknotes. The stamped banknotes were gradually replaced by new Czech and Slovak banknotes. The entire process was completed by the end of August 1993.

${ }^{7}$ This limit corresponded to some USD 140 and less than one month's average wage. At the time of separation, the average monthly wage was CSK 5,175 in the Czech Republic and CSK 4,659 in Slovakia (OECD, 1994). Cash in excess of the limit could be deposited in an account with the Postbank (the actual exchange was carried out by post offices) or sent as a postal money transfer (to be delivered after the separation period). 


\section{THE BREAKUP OF CZECHOSLOVAKIA AND THE OPTIMUM CURRENCY AREA THEORY}

The basic argument of the OCA literature, as stated by Mundell (1961), is the following. When two countries are exposed to asymmetric demand shocks, they can adjust the exchange rate to alter relative prices and mitigate adverse effects of the shocks. However, if these two countries use the same currency, countryspecific monetary policy measures are not possible. If nominal wages are sticky in both countries, relative prices do not adjust in response to the shocks. Therefore, an optimum currency area comprises countries that experience symmetric (positively correlated) shocks, or possess effective mechanisms for mitigating the adverse effects of asymmetric shocks. Such absorption mechanisms can be high inter-country labor mobility or a system of fiscal insurance.

The OCA literature identified a number of criteria which help to "define the optimum currency area, within which the exchange rates should be pegged immutably, but whose rates should fluctuate, or at least be varied, vis-à-vis the outside world" (Kenen, 1969, p. 41). In this section, we attempt to establish whether Czechoslovakia constituted an optimum currency area. Failure to fulfill some of the criteria could have been the reason for the breakup or a source of tension preceding the breakup. We focus on the following criteria of the OCA literature, the correlation of output shocks, inter-regional labor mobility, intensity of bilateral trade, and diversification of industrial structure.

\subsection{Symmetry and Asymmetry of Output Shocks}

Measuring the incidence of shocks is difficult because shocks are not directly observable. Following Bayoumi and Eichengreen (1993), we use a bivariate VAR model to decompose the variations in output into temporary and permanent shocks. ${ }^{8}$ The shocks are denoted temporary and permanent from the point of view of their effect on output; both types of shocks have permanent effects on prices. The methodology is described in great detail in Bayoumi and Eichengreen (1993). Because of space concerns, we do not repeat the description here. We used real and nominal output proxied by net material product (national income) in constant and current prices covering the period from 1948 to 1990. Panel A of Table 1 presents the results.

Our estimates indicate that temporary and permanent shocks affecting the Czech Republic and Slovakia were significantly and positively correlated; moreover, the correlation of temporary shocks is generally higher that that of permanent shocks. To assess the viability of Czechoslovakia as a single currency area,

${ }^{8}$ Bayoumi and Eichengreen (1993) denote permanent shocks as supply shocks and temporary shocks as demand shocks. As Minford (1993) points out, however, this is somewhat misleading. For example, temporary shocks may also reflect transitory supply shocks, policy responses to shocks, and exchange rate adjustments. A similar argument holds for the permanent shocks. 
TABLE 1

Correlation Coefficients of Permanent and Temporary Shocks

A. Czech Republic and Slovakia

Net material product, 1948-1990

0.53

0.83

Net material product, 1960-1990

0.41

0.85

Net material product, $1970-1990$

0.43

0.81

Disposable net material product, 1948-1990

0.34

0.42

Disposable net material product, 1960-1990

0.53

0.51

Disposable net material product, 1970-1990

0.46

0.83

B. EMU, Germany, and the United States

Germany and France ${ }^{a}$

0.54

0.35

Germany and Belgium ${ }^{a}$

0.61

0.33

Germany and Netherlands ${ }^{a}$

0.59

0.17

Germany and United Kingdom ${ }^{a}$

0.11

0.16

North Rhine-Westphalia and Hessen ${ }^{b}$

0.80

0.82

North Rhine-Westphalia and Bavaria ${ }^{b}$

0.69

0.64

Bavaria and Baden-Wurttenberg ${ }^{b}$

0.76

0.82

Hamburg and Bremen ${ }^{b}$

0.14

$-0.21$

Mid-East and New England ${ }^{c}$

0.86

0.79

Mid-East and Great Lakes ${ }^{c}$

0.81

0.60

Mid-East and Rocky Mountains ${ }^{c}$

0.18

$-0.28$

Note. Estimated by a bivariate structural vector autoregressive model. The sources for panel A are the Historical Statistical Yearbook of Czechoslovakia (1985) and the Statistical Yearbook (various volumes), Federal Statistical Office, Prague. For the sources for panel B, see the footnotes.

${ }^{a}$ Bayoumi and Eichengreen (1993), GDP, 1962-1988.

${ }^{b}$ Funke (1997), GDP, 1974-1993.

${ }^{c}$ Bayoumi and Eichengreen (1993), GDP, 1965-1986.

it is instructive to compare this experience with the experiences of other countries in existing currency unions. Panel B of Table 1 reports estimates of the correlations of permanent and temporary shocks for three such unions, the European Economic and Monetary Union (EMU), the Federal Republic of Germany, and the United States. ${ }^{9}$ The correlation of permanent shocks between the Czech and Slovak Republics is between 0.34 and 0.53 for different time periods. This is comparable to the correlations of permanent shocks among the core EMU countries, i.e., Germany, France, Belgium, and the Netherlands. However, our estimates are substantially lower than the correlations of permanent shocks among the core German Federal States, or the core U.S. regions, which fall between 0.69 and 0.86 . On the other hand, the correlation of temporary shocks

${ }^{9}$ Table 1 reports only correlation estimates for selected EMU countries, German federal states, and U.S. regions in order to illustrate our point. For a complete list, see Funke (1997) and Bayoumi and Eichengreen (1993), respectively. 
in former Czechoslovakia was essentially the same order of magnitude as that in Germany and the United States, exceeding 0.80.

Hence, we find that the shocks that affected the two republics of Czechoslovakia were generally symmetric. However, the low correlation of permanent shocks indicates that the degree of economic integration in former Czechoslovakia was in fact lower than that among the core regions of Germany or the core regions of the United States, and only comparable to that of the core members of the EMU. This result is rather surprising, especially since for most of this century, the two republics were part of a single political and monetary union with highly centralized economic policies. The low correlation of permanent shocks probably reflects the high degree of specialization of the two economies (see Section 3.5 for further discussion), and hence their vulnerability to asymmetric developments.

A low correlation of permanent shocks is an important destabilizing factor in currency unions. The countries participating in a union can insure each other against temporary shocks, but permanent shocks require long-term adjustment (Krugman, 1993). This adjustment can be achieved either by migration of factors of production or by changes in relative prices. If labor is immobile, and prices and wages are inflexible, asymmetric permanent shocks create pressure for exchange rate adjustments. Although fiscal transfers can also respond to the permanent shocks, because of their long-term nature, such transfers can become politically costly and give rise to incentives for secession, as argued by Jan Fidrmuc (1999b).

Clearly, the use of data originating from the period of central planning is problematic because the economy was under strict control by the government and prices were not the result of market clearing. ${ }^{10}$ In effect, some of the shocks captured by our analysis were probably caused by government policies rather than by external factors. This may provide a partial explanation for the relatively low correlation of permanent shocks. On the other hand, the central setting of prices may have contributed to the high correlation of temporary shocks because temporary shocks, in this framework, are those that affect only prices but not output in the long term. Hence, deliberate government policies during the Communist period were one of the causes, although probably not the only one, of the relatively low degree of economic integration of the two parts of former Czechoslovakia. Such policies rendered Czechoslovakia more fragile and susceptible to asymmetric shocks, such as those induced by the economic reforms implemented after 1990. Indeed, the reform-induced recession was more profound in Slovakia. From 1990 to 1992, GDP declined by some 15\% in the Czech Republic and by $22 \%$ in Slovakia, and the development of unemployment was even much more asymmetric. 
TABLE 2

Evidence on Convergence in the Former Czechoslovakia

\begin{tabular}{|c|c|c|c|c|c|}
\hline \multicolumn{6}{|c|}{ A. Slovak NMP as a ratio of Czech NMP } \\
\hline Data series & 1950 & 1960 & 1970 & 1980 & 1990 \\
\hline Real NMP & 0.661 & 0.729 & 0.757 & 0.813 & 0.813 \\
\hline Nominal NMP & 0.635 & 0.744 & 0.788 & 0.851 & 0.836 \\
\hline Real disposable NMP & 0.756 & 0.787 & 0.903 & 0.932 & 0.909 \\
\hline Nominal disposable NMP & 0.811 & 0.799 & 0.776 & 0.812 & 0.864 \\
\hline \multicolumn{6}{|c|}{ B. Augmented Dickey-Fuller test statistics for the residual in Eq. (1) } \\
\hline \multicolumn{2}{|c|}{ Data series } & \multicolumn{2}{|c|}{$1950-1990$} & \multicolumn{2}{|c|}{$1970-1990$} \\
\hline \multicolumn{2}{|l|}{ Real NMP } & \multicolumn{2}{|c|}{-1.18} & \multicolumn{2}{|c|}{-2.02} \\
\hline \multicolumn{2}{|l|}{ Nominal NMP } & \multicolumn{2}{|c|}{-1.31} & \multicolumn{2}{|c|}{-2.36} \\
\hline \multicolumn{2}{|c|}{ Real disposable NMP } & \multicolumn{2}{|c|}{-2.06} & \multicolumn{2}{|c|}{-1.02} \\
\hline \multicolumn{2}{|c|}{ Nominal disposable NMP } & \multicolumn{2}{|c|}{-1.89} & \multicolumn{2}{|c|}{-1.45} \\
\hline
\end{tabular}

Note. (Panel A) The sources are the Historical Statistical Yearbook of Czechoslovakia (1985) and the Statistical Yearbook (various volumes), Federal Statistical Office, Prague. (Panel B) Critical values for the null hypothesis of a unit root at 5\% (10\%) significance level are $-2.93(-2.60)$ for the period from 1950 to 1990 and -3.06 (-2.65) for the period from 1970 to 1990 . The number of lags for the residuals was calculated using the Akaike information criterion.

\subsection{Convergence of Per Capita Output}

In a monetary union consisting of two initially unequal entities, convergence can be an important factor of long-term sustainability of the union. Using GDP data for the period from 1970 to 1995, Estrin and Urga (1997) find only limited evidence of convergence within the former Soviet bloc, as well as within particular groupings of former socialist countries. These authors conclude that these results formalize the widely held perception that neither the CMEA, nor the ruble block, nor the former Soviet Union formed an optimal currency area or customs union. Convergence was an important political issue in the former Czechoslovakia. The Communist governments always asserted that resources were being transferred to Slovakia in order to promote its catching up with the Czech lands. We use the available data to evaluate empirically this claim.

Panel A of Table 2 reports the ratio of Slovak and Czech per capita outputs, based on different measures of real and nominal net material product. All measures show that the gap between the Czech Republic and Slovakia decreased considerably. However, this process slowed down or stopped in the 1980's, when the gap between the two countries even increased by some measures. Moreover, the gap was much smaller for disposable NMP, indicating the importance of inter-republic transfers. 
Next, we test for achieved convergence following the approach of Bernard and Durlauf (1991). Stochastic convergence in per capita output implies the relationship

$$
Y_{i, t}=Y_{j, t}+\nu_{i, j, t}
$$

where $\nu_{\mathrm{i}, \mathrm{j}, \mathrm{t}} \sim N\left(0, \sigma^{2}\right)$ is an error term. The log of per capita output in country $i$ converges to the $\log$ of per capita output in country $j$ if the error term $\nu_{i, j, t}$ is stationary in levels. The results of the test for the presence of a unit root in the error term yielded by Eq. (1) are presented in Panel B of Table 2. Based on the results, we can reject the hypothesis of stochastic convergence in the sense of Bernard and Durlauf (1991). Accordingly, the Czech and Slovak economies have not converged either from 1950 to 1990 or from 1970 to 1990 , despite the stated objective to achieve such convergence. Our result stands in contrast to those of Estrin and Urga (1997) who find evidence of achieved convergence for the Czech Republic and Slovakia, as well as for several other pairs of countries, from 1970 to $1990 .{ }^{11}$ For comparison, Bernard and Durlauf (1991) reject convergence at the $5 \%$ level for most of the tested countries, except for a small number of core western European countries.

\subsection{Inter-regional Labor Mobility}

Labor mobility substitutes for the absence of autonomous monetary policy in a monetary union. Unemployed workers migrate from regions hit by an adverse shock to regions with more favorable conditions, thus equilibrating the effects of asymmetric shocks. In a hypothetical union with perfect factor mobility, regions would adjust to asymmetric shocks immediately. When labor mobility is low and prices and wages rigid, effects of asymmetric shocks persist and currency unions have to rely on other mechanisms, such as fiscal transfers, to absorb them. Accordingly, it is often argued that the viability of the EMU can be endangered by a low degree of labor mobility within and across member countries, e.g., Eichengreen $(1993,1998)$. Similarly, if labor mobility were low in the former Czechoslovakia, this could have contributed to economic tensions that eventually lead to the demise of the Czech-Slovak monetary union.

There were few, if any, cultural, religious, or linguistic barriers to labor mobility in the former Czechoslovakia, and there were no legal restrictions on migration across the Czech-Slovak border. This has not changed after the breakup of Czechoslovakia as the two new countries agreed to preserve the common labor market indefinitely. Yet, the differences in unemployment rates

${ }^{11}$ The reason for this difference may be that they use a different data source (they use data reported by the World Bank, whereas we use data reported by the Czechoslovak Statistical Office) or a different data transformation (they deflate the data to 1987 constant prices and convert them to U.S. dollars using the commercial exchange rate). 
were substantial. In December 1992, the average unemployment rate reached $10.4 \%$ in Slovakia and 2.6\% in the Czech Republic. In December 1993, in the wake of the breakup, the disparity in unemployment rates was even higher, with $14.4 \%$ in Slovakia and 3.5\% in the Czech Republic. Regional differences in unemployment were even more dramatic; the minimum and maximum regional unemployment rates in December 1992 were 0.3 and 6\% in the Czech Republic (0.3 and $8.7 \%$ in December 1993) and 3.8 and $19.3 \%$ in Slovakia (4.5 and 26.4\% in December 1993). This pattern of regional distribution of unemployment suggests that the process of economic transition has had strongly asymmetric effects on the two parts of Czechoslovakia.

Official statistics ${ }^{12}$ on labor mobility in the former Czechoslovakia reveal that the Czechs were more mobile than the Slovaks. In 1990, internal migration, i.e., migration across county boundaries ${ }^{13}$ but within the borders of the republic, amounted to 1.57 and $0.94 \%$ of Czech and Slovak populations, respectively. On the other hand, the Slovaks were more likely to migrate across the inter-republic border as $0.07 \%$ of Czechs and $0.19 \%$ of Slovaks migrated across the CzechSlovak border in that year. Eichengreen (1998) reports that internal migration amounted to $1.1 \%$ in the UK and Germany and $0.6 \%$ in Italy. However, these figures refer to substantially larger regions than the Czech and Slovak counties. For comparison, $0.69 \%$ of Czechs and $0.34 \%$ of Slovaks moved across the boundaries of administrative regions in 1990. Accordingly, labor mobility in the former Czechoslovakia appears relatively low when compared with Western Europe.

Despite the pervasive regional disparities in unemployment rates, labor mobility actually declined during the course of economic transition. Internal migration in the Czech Republic fell to $1.44 \%$ in $1992,0.91 \%$ in 1994 , and $0.84 \%$ in 1996. Slovak internal migration fell also, albeit more slowly, to $0.81 \%$ in 1992 , $0.78 \%$ in 1994, and $0.75 \%$ in $1996 .{ }^{14}$ Migration across the Czech-Slovak border fell too; only 0.01 and $0.06 \%$ of Czechs and Slovaks, respectively, crossed the new border in $1996 .^{15}$

Given the evidence pointing to increasing regional disparities in unemploy-

${ }^{12}$ These statistics are from various issues of the Statistical Yearbook of Czechoslovakia, or that of the Czech Republic or Slovakia.

${ }^{13}$ There were 76 counties in Czech Republic and 38 in Slovakia. These were further aggregated into eight regions in the Czech Republic and four regions in Slovakia.

${ }^{14}$ Several explanations can be suggested to account for this fall in mobility. First, the removal of some restrictions on the housing market resulted in sharp increases in rents and real estate prices. Second, commuting to work is probably now more common. Third, with the fall of Communism, the formal requirement of reporting one's change of residence is probably more often ignored.

${ }^{15}$ On the other hand, some 59 thousand Slovak citizens, including commuters, were employed in the Czech Republic in 1995 and about 72 thousand in 1996. This corresponded to 2.3 and 2.8\% respectively, of the Slovak labor force and certainly helped mitigate the Slovak unemployment problem, with the Slovak unemployment rate standing at 13.1 and $12.8 \%$ in the respective years. 
ment rates, on the one hand, and falling inter-regional migration, on the other hand, the efficacy of labor mobility in mitigating adverse effects of asymmetric shocks appears low. To study the relationship between inter-regional migration and the effects of asymmetric shocks, we performed a regression analysis of migration at the county level. The data are based on records in municipal population registers and, therefore, do not distinguish between employmentrelated mobility and other migration. ${ }^{16}$ The data report total migratory inflows and outflows for 76 Czech and 38 Slovak counties for the period from 1992 to 1995. ${ }^{17}$ The two capitals, Prague and Bratislava, are reported as one observation each so that migratory flows among the urban districts within these two cities are not included in the analysis.

According to the traditional theory (Todaro, 1969), migration should be positively related to the expected income differential, i.e., the wage differential adjusted for the probability of finding employment, between the regions of origin and destination. Accordingly, our data should reveal a negative relationship between migration and the unemployment rate, and a positive relationship between migration and wages.

We performed the analysis using as the dependent variables gross inflow and outflow rates, i.e., inflow and outflow divided by the county's population by the end of the year, as well as net inflow rate, i.e., net inflow divided by population. Interpretation of the results is complicated by the fact that inflow and outflow rates are strongly correlated; the correlation coefficient across the full data set is 0.89. If certain variables affect both inflows and outflows, the estimated coefficients for the net inflow rate will be biased (Bauer and Zimmerman, 1995). Therefore, we look at both gross as well as net migration flows. The results are reported in Table 3.

First, we regressed migration on the regional unemployment rate and the ratio of the region's average wage to the national average wage, both lagged by one year. Dividing wages by the respective year's national average wage should remove the effects of nominal wage growth common to all regions. The regressions also included dummy variables for the individual years with 1992 as the reference year. The results are reported in Panel A for the Czech Republic and in Panel C for Slovakia. Accordingly, unemployment has a significantly negative effect on both gross inflows and outflows in the Czech Republic, although the effect on inflows is more significant and about twice as large as the effect on outflows. The effect on net inflows is negative and significant, as expected. Surprisingly, unemployment does not significantly affect migration in Slovakia,

${ }^{16}$ The sources are Pohyb obyvatelstva, Czech Statistical Office, various issues, and Statisticka rocenka okresov Slovenskej republiky za roky 1990-1995, Statistical Office of the Slovak Republic, 1997, respectively.

${ }^{17}$ The data report the total inflow and outflow of migrants per county per year. Hence, we do not have the matrix of migration flows between individual counties, only the totals per each county. 
despite its higher unemployment and greater regional disparities. The wage ratio has a strong and positive effect on gross inflows and outflows in both countries, whereas it is only significantly and positively related to net inflows in Slovakia. ${ }^{18}$ The effect of wages on gross inflows is almost twice as large in Slovakia as it is in the Czech Republic. Hence, it appears that labor mobility in the Czech Republic is driven by regional differences in both unemployment and wages, whereas in Slovakia it only responds to wage differentials.

It is possible, however, that the coefficient estimates obtained in the basic regressions are biased because of omitted variables. Therefore, we estimated the migration equations with additional explanatory variables, both economic and demographic characteristics that possibly affect migration. The economic variables are, first, a measure of the size of the nascent private sector, proxied by the number of small private unincorporated entrepreneurs, excluding farmers, as a percentage of the county's population, and, second, employment in industry and agriculture as a percentage of total employment. The demographic variables include the share of the Hungarian minority in Slovakia, the proportion of county residents who are above retirement age, the proportion of county residents who have a university education, and the log of population density as a measure of urbanization. ${ }^{19}$ The results of these extended regressions are reported in Panels B and D for the Czech Republic and Slovakia, respectively.

The unemployment rate now is clearly insignificant for both countries, whereas the wage ratio remains significant and retains its sign, and the magnitude of the coefficient estimate is more than tripled for the Czech Republic. However, wages have a positive effect on both inflows and outflows, which is somewhat troubling. The reason for this might be that due to high migration costs, a large fraction of those who move are high-wage earners. Similarly, the number of entrepreneurs in the regions, standing as a proxy for the extent of the emerging private sector, is significantly and positively related to both inflows and outflows. Perhaps this reflects the effect of high migration costs again and the fact that private sector wages typically exceed those paid in state-owned enterprises. Hence, the regions with high wages and/or active private sector show high mobility, in terms of both inflows and outflows.

Several other variables affect migration significantly. The share of the Hungarian minority is negatively related to gross inflows and outflows; migration to

${ }^{18}$ Replacing the wage ratio with real wage growth yielded insignificant results. Dividing the unemployment rate by the national unemployment rate did not change the results.

${ }^{19}$ However, as the economic and demographic data were not available for every year, we used economic data as of 1992 and demographic data as of 1991 (census year). The use of annual data would be preferable, although there is usually not much year-to-year variability in demographic characteristics. The available economic indicators also show a high degree of stability across time, with correlation coefficients between 1992 and 1995 (the two years for which we have data) around or above 0.9 . 
TABLE 3

Determinants of Inter-regional Migration: Czech Republic and Slovakia

Inflow rate

Outflow rate

Net inflow rate

A. Basic regression,

Czech Republic

Constant

Dummy 93

Dummy 94

Dummy 95

Unemployment rate (lagged)

Wage ratio (lagged)

Adj. $R^{2}$

$\begin{array}{ccc}0.964 * *(5.46) & 0.893 * *(5.63) & 0.072(0.55) \\ -0.173 * *(-3.63) & -0.100 *(-2.24) & -0.073 * *(-2.58) \\ -0.258 * *(-5.84) & -0.267 * *(-6.45) & 0.009(0.33) \\ -0.283 * *(-6.26) & -0.301 * *(-7.29) & 0.019(0.67) \\ -0.037 * *(-3.87) & -0.018 *(-1.92) & -0.020 * *(-3.86) \\ & & \\ 0.508 * *(2.87) & 0.418 * *(2.74) & 0.087(0.70) \\ 0.188 & 0.234 & 0.068\end{array}$

B. Extended regression,

Czech Republic

Constant

Dummy 93

Dummy 94

Dummy 95

Unemployment rate (lagged)

Wage ratio (lagged)

Retirees

University educated

Population density [log]

Entrepreneurs

Industrial employment

Agricultural employment

Adj. $R^{2}$

$-0.446(-0.95)$

$-0.419(-1.14)$

$-0.030(-0.09)$

$-0.117 * *(-2.61)$

$-0.069(-1.75)$

$-0.048(-1.76)$

$-0.199 * *(-4.76)$

$-0.219 * *(-6.08)$

$0.021(0.75)$

$-0.182 * *(-3.94)$

$-0.219 * *(-5.66)$

$0.038(1.29)$

$-0.006(-0.56)$

$-0.001(-0.11)$

$-0.005(-0.71)$

$$
\begin{aligned}
& 1.685^{* *}(5.86) \\
& 0.011(1.23) \\
&-0.019(-1.62) \\
&-0.030(-0.81) \\
& 0.038^{* *}(2.85) \\
&-0.009(-3.54) \\
& 0.010 *(2.05) \\
& 0.355
\end{aligned}
$$

$$
\begin{aligned}
& 1.567 * *(6.56) \\
- & 0.002(-0.29) \\
- & 0.037 * *(-3.56) \\
& 0.038(0.96) \\
& 0.035 * *(3.72) \\
- & 0.009 * *(-4.19) \\
& 0.016^{* *}(3.95) \\
& 0.441
\end{aligned}
$$

$0.119(0.71)$

$0.014 *(2.09)$

$0.018 *(2.06)$

$-0.068 *(-2.16)$

$0.003(0.45)$

$0.000(0.11)$

$-0.007(-1.71)$

0.102

$$
\begin{gathered}
-0.040(-0.19) \\
0.001(0.02)
\end{gathered}
$$

$$
0.536 * *(3.80)
$$

$-0.579 * *(-2.97)$

$-0.099 *(-2.14)$

$-0.105 * *(-3.52)$

$0.106 * *(2.98)$

$-0.186 * *(-3.95)$

$-0.249 * *(-7.44)$

$0.149 * *(4.58)$

$-0.305^{* *}(-8.89)$

$0.119 * *(3.94)$

$-0.004(-1.30)$

$-0.002(-0.67)$

$-0.003(-1.09)$

(lagged)

Wage ratio (lagged)

Adj. $R^{2}$

$$
0.948 * *(4.89)
$$$$
0.386 * *(3.12)
$$

0.492

$$
0.565 * *(3.14)
$$

0.196

D. Extended regression,

$$
\text { Slovakia }
$$

\section{Constant}

Dummy 93

Dummy 94

Dummy 95

Unemployment rate

(lagged)

$$
\begin{array}{lll}
-0.781 * *(-2.78) & 0.067(0.28) & -0.853 * *(-3.72) \\
0.002(0.06) & -0.097 * *(-3.83) & 0.099 * *(3.24) \\
-0.104 * *(-2.66) & -0.249 * *(-8.49) & 0.145 * *(5.26) \\
-0.192 * *(-4.63) & -0.303 * *(-9.84) & 0.111 * *(4.26) \\
-0.003(-0.84) & -0.001(-0.37) & -0.002(-0.75)
\end{array}
$$


TABLE 3-Continued

\begin{tabular}{lccc}
\hline & Inflow rate & Outflow rate & Net inflow rate \\
\hline Wage ratio (lagged) & $0.942^{* *}(4.12)$ & $0.567 *(2.71)$ & $0.381^{*}(2.11)$ \\
Hungarian minority & $-0.002^{*}(-2.32)$ & $-0.004 *(-5.03)$ & $0.001^{*}(2.44)$ \\
Retirees & $0.041^{* *}(6.96)$ & $0.028^{* *}(5.98)$ & $0.013 * *(2.97)$ \\
University educated & $-0.002(-0.21)$ & $-0.026^{* *}(-3.03)$ & $0.024^{* *}(3.44)$ \\
Population density [log] & $-0.035(-1.74)$ & $0.011(0.64)$ & $-0.045^{* *}(-2.63)$ \\
Entrepreneurs & $0.056^{* *}(2.92)$ & $0.035^{*}(2.38)$ & $0.022^{*}(2.39)$ \\
Industrial employment & $-0.004^{*}(-2.07)$ & $-0.007 * *(-5.15)$ & $0.003 *(2.08)$ \\
Agricultural employment & $0.006^{* *}(2.69)$ & $-0.001(-0.42)$ & $0.007 * *(3.29)$ \\
Adj. $R^{2}$ & 0.556 & 0.656 & 0.365 \\
\hline
\end{tabular}

Note. The data are pooled over the period from 1992 to 1995. T-statistics (heteroscedasticity robust) are reported in parentheses. The dependent variables are the gross inflow and outflow rates and the net inflow rate as a percentage of the region's population, respectively. The wage ratio is the average wage divided by the national average wage of that year. The unemployment rate and the wage ratio are lagged one year. Hungarian minority refers to the percentage of a county's population as of 1991. Retirees are the persons above the legally stipulated retirement age as a percentage of population as of 1991. University educated refers to the county's residents with a university education, as a percentage of the total population as of 1991. Population density is the log of persons per squared kilometer. Entrepreneurs are unincorporated entrepreneurs and self-employed persons, excluding farmers, expressed as a percentage of the county's population as of 1992. Industrial and agricultural employment are expressed as a percentage of total employment as of 1992.

* Significant at the $1 \%$ level.

** Significant at the $5 \%$ level.

and from regions with a sizable Hungarian population is apparently restricted by linguistic and/or cultural barriers (Jarko Fidrmuc, 1995). Urban regions, i.e., those with high population density, experience a net outflow of labor. The proportion of university-educated residents has a particularly strong negative effect on gross outflows and a positive effect on net inflows. Industrial regions show lower gross flows, whereas the opposite is true for agricultural regions although the effect on outflows is insignificant for Slovakia.

In summary, it appears that the relationship between inter-regional migration and unemployment in the former Czechoslovakia from 1992 to 1995 was weak or nonexistent. Hence, labor mobility was rather ineffective in mitigating adverse effects of asymmetric shocks. The potential effect of migration on unemployment differentials is rather small; a rise of the unemployment rate by one percentage point leads to net outflows corresponding to 0.02 percentage points of the region's population in the Czech Republic and 0.003 percentage points in Slovakia according to the basic regressions reported in Panels A and C. Moreover, the effect is stronger in the Czech Republic, despite a greater need for such adjustments in Slovakia.

The extent of inter-county migration was also extremely low; although gross 
flows were not negligible, ${ }^{20}$ the average net migration rate was only $0.07 \%$ in the Czech Republic and $0.01 \%$ in Slovakia annually. Again, labor mobility was greater in the Czech Republic than in Slovakia, despite higher unemployment rates and a greater need for mitigation of asymmetric shocks in Slovakia.

\subsection{The Intensity of Bilateral Trade}

The benefits of a single currency rise with the volume of trade. Therefore, countries that trade with each other extensively will benefit more from monetary integration. For this reason, intensity of mutual trade is one of the main criteria for assessing the benefits and costs of integration or disintegration. In addition, as Frankel and Rose (1998) argue, a high intensity of mutual trade increases the correlation of economic shocks between the respective countries. Accordingly, countries engaging in mutual trade extensively will also generally fulfill the criterion of symmetry of shocks because the latter is in fact endogenous. ${ }^{21}$

The extent of bilateral trade between the Czech and Slovak Republics was and has remained relatively high. Due to the different sizes of the two republics (the population of Slovakia is roughly one half that of the Czech Republic) Slovakia has been dependent on the Czech Republic to a much greater extent than the reverse. In 1991, the Czech Republic accounted for about 50\% of Slovak exports and imports. On the other hand, Slovakia accounted for only about a third of Czech trade. ${ }^{22}$ This points to an extraordinarily high degree of interdependence between the two countries prior to the breakup. Slovakia was the Czech Republic's most important trading partner and vice versa until the split. Such a pattern of bilateral trade is not typical for two small open economies. For example, Norway only accounts for $6 \%$ of Sweden's exports, although the relationship between these two countries could be compared with that between the Czech Republic and Slovakia in terms of similarities in culture, language, relative and absolute size, geographical proximity, openness, and liberalization of mutual trade. After the breakup, the share of Slovak trade with the Czech Republic fell to about $25 \%$ of total exports and imports in 1997. Czech trade with Slovakia declined to 13 and $8 \%$ of total exports and imports in 1997, respectively.

The comparison of Czech-Slovak trade with other countries is difficult because bilateral trade depends on countries' sizes, distance, language, and other factors. The

${ }^{20}$ Gross inflow and outflow rates were, respectively, 1.14 and $1.07 \%$ in the Czech Republic and 0.72 and $0.71 \%$ in Slovakia.

${ }^{21}$ However, this proposition is the subject of controversy. Krugman (1993) argues in favor of the opposite relationship, that greater integration within monetary unions fosters greater specialization of regions and thus increases the incidence of asymmetric shocks.

${ }^{22}$ These figures are based on statistics reporting the deliveries of Slovak medium-sized and large enterprises, i.e., enterprises with more than 25 employees, to and from the Czech Republic. Hence, these data are not directly comparable with customs statistics on trade flows, which are available since 1993. 
usual empirical approach is to apply the gravity model ${ }^{23}$ (Linnemann, 1966), which relates the trade flows between two countries to the importer's demand, the exporter's supply, and the trade costs. Importer's demand and exporter's supply are proxied by the countries' gross domestic products (GDP). Trade costs, i.e., transport and transaction costs, are measured by the geographical distance.

The gravity model was used by Hamilton and Winters (1992) to assess the trade potential of Eastern Europe and the former Soviet Union. It was also used to analyze the reorientation of trade flows of countries participating in the various economic integration arrangements. Abraham et al. (1997) applied the gravity model to historical trade data of Belgium and showed that the creation of the European Community reoriented Belgian exports toward the current core countries of the European Union. Cheikbossian and Maurel (1998) estimate the gravity model over the period from 1980 to 1993 to analyze the disintegration of the Council of Mutual Economic Assistance (CMEA). We follow this approach and estimate the effects of preferential trade relations between the Czech Republic and Slovakia before and after the breakup of Czechoslovakia and compare the specific case of the former Czechoslovakia with the other newly independent states in Eastern Europe. The equation implied by the gravity model is

$$
\begin{aligned}
M=\beta_{1}+\beta_{2} Y_{\mathrm{M}}+\beta_{3} Y_{\mathrm{X}}- & \beta_{4} d+\beta_{5} \mathrm{CB}+\beta_{6} \mathrm{ENG}+\beta_{7} \mathrm{CS}+\beta_{8} \mathrm{EC} \\
& +\beta_{9} \mathrm{~V} 4+\beta_{10} \mathrm{EA}+\beta_{11} \mathrm{BRU}+\beta_{12} \mathrm{BS}+\epsilon,
\end{aligned}
$$

where $M$ denotes the bilateral imports, $Y$ stands for the GDP of the exporting and the importing country, denoted by subscripts $\mathrm{X}$ and $\mathrm{M}$, respectively, $d$ is the distance between the capital cities of both countries, and $\epsilon$ is the disturbance term. All variables are in logs. In addition, we include dummies to control for the effects of a common border (CB), English speaking countries (ENG), the European Union (EC), the Visegrád countries (V4), and the Europe Agreements between the European Union and the associated countries (EA). ${ }^{24}$ Additional dummy variables are used to measure the effects of preferential trade relations among the Czech Republic and Slovakia (CS), Belarus, Russia, and Ukraine (BRU), and the Baltic States (BS).

We estimate Eq. (2) using a data set of bilateral trade flows between OECD countries and Eastern European countries for each of the seven available years from 1991 to 1997. The results are reported in Table 4. This data set provides

${ }^{23}$ We are grateful to an anonymous referee for suggesting this approach.

${ }^{24}$ The EC dummy denotes the European Community's 12 member states from 1991 to 1994 and the European Union's 15 member states since 1995. The Visegrád group includes the Czech Republic, Hungary, Poland, and Slovakia. We do not include EFTA because its role was largely insignificant during the analyzed period. The dummy for Europe Agreements denotes trade flows between the current member states of the European Union, including the former EFTA countries, and the associated countries, i.e., Bulgaria, Czech Republic, Estonia, Hungary, Latvia, Lithuania, Poland, Romania, Slovakia, and Slovenia, during the whole analyzed period. 


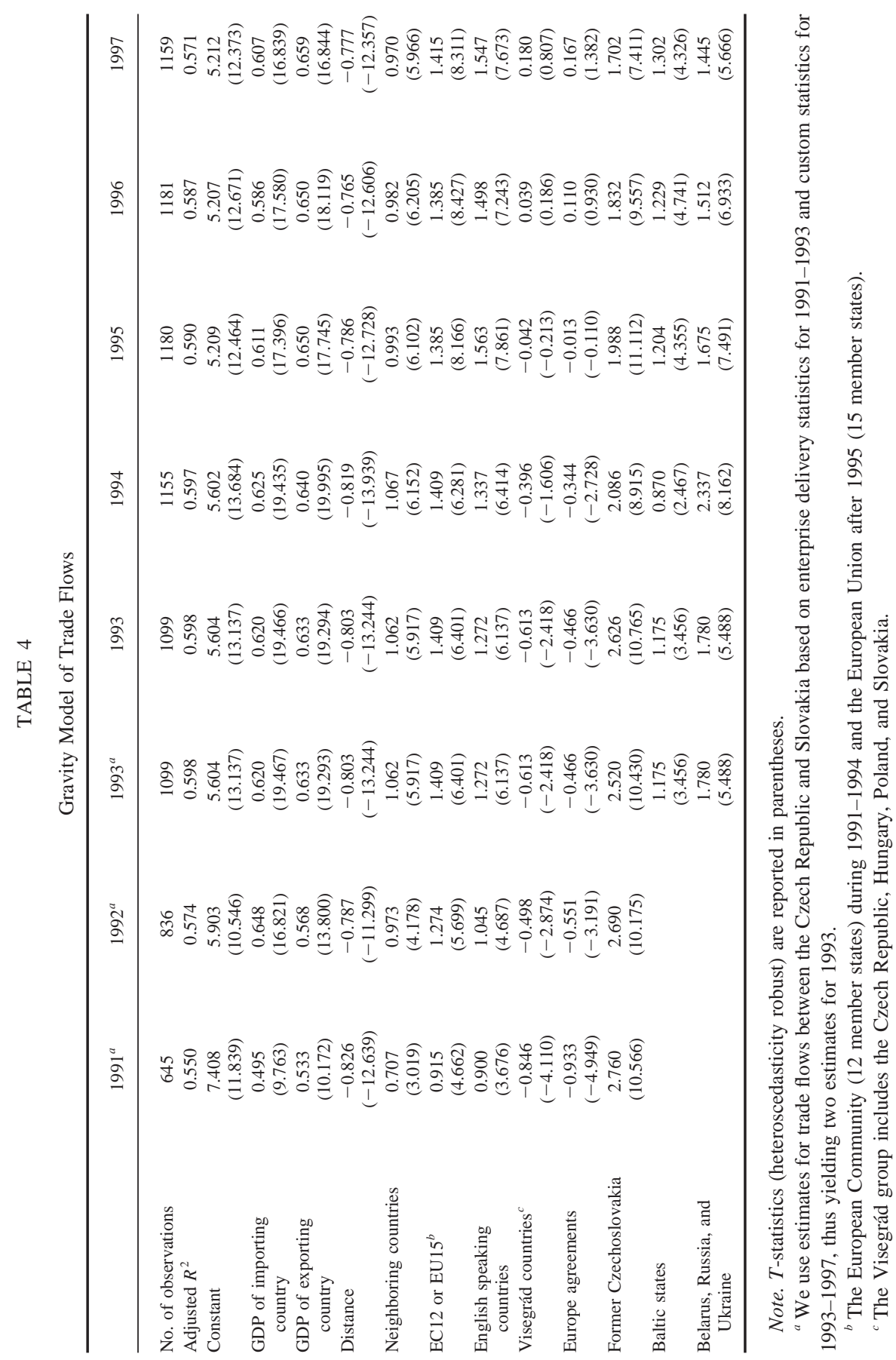


between 600 and 1200 bilateral trade flows, depending on data availability and the creation of new independent states during the period analyzed. All data on trade flows and aggregate output are from IMF publications, Direction of Trade for trade flows and International Financial Statistics for GDP. Missing data on aggregate output in some post-communist countries were supplemented from the EBRD Transition Report 1998.

The bilateral trade flows between the Czech Republic and Slovakia were not reported officially before the breakup. Therefore, we estimate the trade flows in the two years before the breakup and in the first post-breakup year, i.e., 1991 to 1993, based on data for enterprise deliveries between the two entities. ${ }^{25}$ Two caveats apply to these data. First, the data are based on enterprise reports, not customs statistics. Second, the data only include deliveries of enterprises with 25 and more employees. Therefore, the results obtained with these data and with official statistics are not directly comparable. Nonetheless, we believe it is instructive to use the data to estimate the effects of preferential trade relations prior to the breakup. Moreover, the estimates obtained for 1993 with the two types of data are quite similar (see Fig. 1) and are not significantly different from each other.

As in previous studies, the gravity model provides a good explanation of the bilateral trade of the selected countries, as the adjusted $R$ squared lies between 0.5 and 0.6. All of the newly independent countries in Eastern Europe trade more intensively with their previous counterparts than with other countries. The estimated coefficient for the former Czechoslovakia was 2.76 in 1991. After the transformation of logs to absolute levels, the trade flows within Czechoslovakia exceeded the normal level, i.e., trade in absence of any preferential relations, by nearly sixteen times. Moreover, this factor seems to be relatively stable until the division of Czechoslovakia in 1993. The disintegration of the common state caused a sharp decline of bilateral trade (see Fig. 1). The coefficient for the former Czechoslovakia fell to 2.09, which corresponds to a trade volume eight times higher than the normal level, in 1994, and finally to only 1.70 , which is about five times the normal level, in 1997.

Furthermore, it is important to note that the trade intensity as measured by the estimated coefficient for trade relations between the Czech Republic and Slovakia has declined continuously since 1993, although the bilateral trade volume recovered slightly between 1993 (minimum value) and 1997. Together with the declining shares of the intra-Czechoslovak trade in the countries' total trade, this indicates that the trade growth in recent years consists of three components. First, trade intensity declined in the wake of the disintegration of Czechoslovakia. Second, the trade level increased, reflecting high growth, especially in Slovakia,

${ }^{25}$ The sources of the data are Vzajomne dodavky medzi SR a CR: 1.-4. stvrtrok 1992, Statistical Office of the Slovak Republic, 1993, and Predaj tovarov medzi SR a CR v roku 1993 podla stvrtrokov, Statistical Office of the Slovak Republic, 1994. 


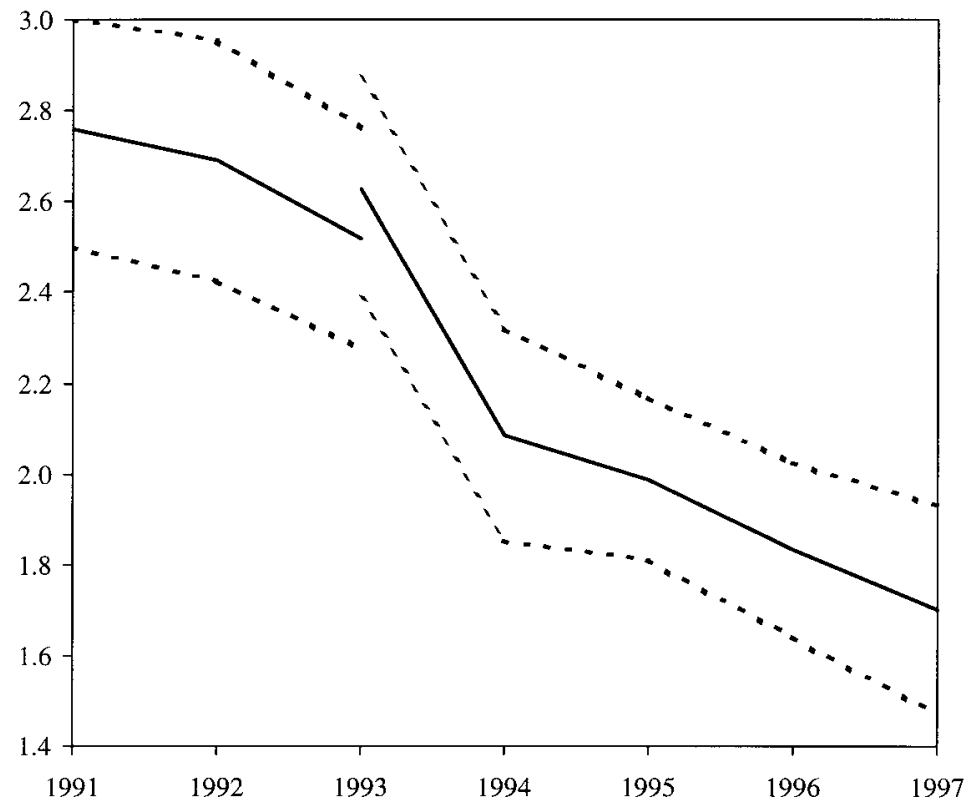

FIG. 1. The effects of preferential trade relations between the Czech and Slovak Republics. The solid line shows the development of the coefficient estimated for the former Czechoslovakia as defined by Eq. (2). The confidence bands (dotted lines) were computed as the estimated coefficient \pm standard errors. The covariance matrices of the coefficients are corrected for possible heteroscedasticity. The discontinuity in 1993 is caused by the fact that we used two different data sources. The coefficients for 1991 to 1993 are estimated with enterprise data, whereas the coefficients for 1993 to 1997 are estimated with the official trade statistics; hence, we have two estimates for 1993.

in recent years. Finally, a reduction of trade barriers between the Visegrád countries, which were reflected in the negative coefficients for the Visegrád group until 1996, increased trade intensity between these countries, including Czech and Slovak trade. However, the importance of the last effect is relatively minor.

Jarko Fidrmuc (1999) argues that the customs union between the Czech and Slovak Republics is largely comparable to trade liberalization within the European Union. Actually, the coefficient for the former Czechoslovakia seems to converge to the trade level in the European Union. In 1997, trade between two EU countries was more than four times higher than the normal trade. Jarko Fidrmuc (1999) suggests that the trade intensity between the Czech Republic and Slovakia could stabilize at about this level if no further relaxation of economic relations takes place. On the other hand, further decline of bilateral trade intensity could be expected if the customs union is dissolved, because of, for example, the accession of the Czech Republic to the European Union and the exclusion of Slovakia from the first wave of the EU eastward enlargement. 
TABLE 5

Commodity Structure of Czech and Slovak Foreign Trade, 1993

\begin{tabular}{|c|c|c|c|c|c|c|}
\hline \multirow[b]{2}{*}{ Category } & \multicolumn{2}{|c|}{ Czech Republic } & \multicolumn{2}{|c|}{ Slovakia } & \multicolumn{2}{|c|}{ Bilateral trade } \\
\hline & Exports & Imports & Exports & Imports & $\mathrm{CZ} \rightarrow \mathrm{SK}$ & $\mathrm{SK} \rightarrow \mathrm{CZ}$ \\
\hline SITC0, food and animals & $6.5 \%$ & $6.3 \%$ & $5.5 \%$ & $7.3 \%$ & $7.6 \%$ & $5.5 \%$ \\
\hline SITC1, beverages and tobacco & $1.2 \%$ & $1.1 \%$ & $0.9 \%$ & $1.5 \%$ & $2.5 \%$ & $1.4 \%$ \\
\hline SITC2, Crude materials, excl. fuels & $6.1 \%$ & $5.0 \%$ & $4.9 \%$ & $5.2 \%$ & $2.2 \%$ & $4.3 \%$ \\
\hline SITC3, Mineral fuels and related & $6.2 \%$ & $11.1 \%$ & $4.9 \%$ & $20.9 \%$ & $10.2 \%$ & $6.6 \%$ \\
\hline SITC4, animal and vegetable oils & $0.2 \%$ & $0.4 \%$ & $0.1 \%$ & $0.2 \%$ & $0.4 \%$ & $0.2 \%$ \\
\hline SITC5, chemicals & $9.5 \%$ & $12.1 \%$ & $12.0 \%$ & $11.4 \%$ & $12.3 \%$ & $14.4 \%$ \\
\hline SITC6, Manufactured goods & $29.9 \%$ & $15.9 \%$ & $38.8 \%$ & $15.1 \%$ & $25.1 \%$ & $34.0 \%$ \\
\hline SITC7, machinery and transport equip. & $27.6 \%$ & $36.1 \%$ & $19.4 \%$ & $29.3 \%$ & $27.3 \%$ & $23.8 \%$ \\
\hline SITC8, misc. manufactured articles & $12.7 \%$ & $11.7 \%$ & $13.4 \%$ & $9.0 \%$ & $12.3 \%$ & $9.8 \%$ \\
\hline SITC9, others & $0.0 \%$ & $0.4 \%$ & $0.1 \%$ & $0.2 \%$ & $0.1 \%$ & $0.0 \%$ \\
\hline
\end{tabular}

Sources. Czech Statistical Office and the Statistical Office of the Slovak Republic.

Note. $\mathrm{CZ} \rightarrow \mathrm{SK}$ refers to Czech exports to Slovakia; $\mathrm{SK} \rightarrow \mathrm{CZ}$ indicates Slovak exports to the Czech Republic.

Furthermore, the trade relations between the Czech Republic and Slovakia were, and still are, more intense than those among Belarus, Russia, and Ukraine, or the Baltic States. Similarly, as in the case of the former Czechoslovakia, the trade intensity among Belarus, Russia, and Ukraine is falling rapidly to about the level of EU trade intensity, while trade among the Baltic States is relatively stable at a much lower level.

\subsection{The Diversification of Industrial Structure}

Kenen (1969) argues that for a well-diversified economy the importance of asymmetric shocks will be much smaller than for a less-diversified economy. If the output and exports of a country are sufficiently diversified, shocks affecting specific industries will not have an equally profound effect on the economy as a whole. On the other hand, should exports be heavily biased toward certain industries, shocks affecting these industries will also have significant effects on the overall business cycle of the country. This, in turn, increases the incidence of asymmetric shocks within the currency union.

The structures of output of the Czech Republic and Slovakia do not appear dramatically different from each other; manufacturing is the most important category after services, and it accounts for about a quarter of output. Table 5 reports the commodity structures of Czech and Slovak foreign trade. Manufacturing, consisting of SITC categories 6, 7, and 8, accounts for the greatest part of exports, i.e., $70 \%$ of Czech exports and 64\% of Slovak exports. However, Slovak 
exports are more biased toward manufactured products with relatively low value-added (SITC 6). On the other hand, machinery and transport equipment (SITC 7) dominate Czech exports. On the import side, SITC 7 is relatively more important for the Czech Republic, whereas Slovakia has a greater share of mineral fuels (SITC 3). The commodity structure of bilateral trade between the two countries is not much different from their overall export patterns.

However, while the structures of output appear similar at the aggregate level, there were greater differences at the disaggregate level. In particular, large parts of Slovak industry were built only after the Communist takeover in 1948 within the policy of industrialization of Slovakia. Hence, Slovak industry was much more affected by the communist political objectives, in particular the emphasis on heavy engineering, metallurgy, and chemical industry (Pavlinek, 1995; Capek and Sazama, 1993). As a result, Slovakia was more dependent on trade with the member countries of the Council of Mutual Economic Assistance (CMEA) and thus was more adversely affected by the collapse of the CMEA trade. The shares of exports to the CMEA and EU in 1991 were 42 and 34\%, respectively, compared to 35 and $43 \%$ for the Czech Republic (Fidrmuc and Fidrmuc, 1997, p. 194).

Slovakia also had a greater concentration of military-equipment industry. The latter was particularly important, since the output of this industry in Czechoslovakia fell by $85 \%$ between 1987 and 1992. This decline also affected Slovakia disproportionately. Whereas Slovakia accounted for $60 \%$ of Czechoslovak military-equipment production in 1987 , its share fell to $40 \%$ by $1992 .{ }^{26}$ Finally, Slovak industry was also more strongly regionally concentrated as enterprises were, on average, larger and often constituted the dominant source of regional employment.

In summary, the output and foreign trade of the Czech Republic and Slovakia seemed sufficiently diversified and the exports of both countries showed similar commodity structures. However, the greater dependence of Slovakia on heavy and military-equipment industries, as well as its stronger orientation towards the CMEA, may have been sources of asymmetric developments, in particular during the economic transition in the early 1990's.

\section{BENEFITS AND COSTS OF THE BREAKUP}

The breakup of Czechoslovakia was undoubtedly costly in the short term. As our discussion in Section 3.4 illustrates, the trade between the Czech Republic and Slovakia declined substantially after 1993, even though they retained a customs union. Moreover, the two new countries had to bear the one-time costs

${ }^{26}$ These are figures reported by Dedek et al. (1995, p. 56) and Kiss (1993, p. 1046). According to Kiss, military industry accounted for $3 \%$ of Czechoslovak GDP and $10.5 \%$ of industrial output in 1987. 
of creating new government institutions, separating their currencies, and enforcing the new border. Sujan and Sujanova (1994) estimate that the breakup reduced the Czech GDP by 2.2 percentage points during the first half of $1993 .{ }^{27}$ The effect on Slovakia was certainly even greater, as many of the costs of independence are not related to country size. Overall, Slovakia's GDP fell by 4\% during 1993, whereas Czech GDP fell by $1 \%$.

Related to the benefits and costs of Czechoslovakia's breakup is the question of fiscal transfers. Fiscal transfers generally serve two purposes, redistribution or equalization of per capita incomes and risk sharing. The latter type of fiscal transfer is particularly important when unions are exposed to asymmetric output shocks. Von Hagen (1998) surveys the empirical literature on intra-national fiscal transfers and shows that that both types of transfers are substantial in size in the countries studied. Throughout Czechoslovakia's post-war history, Slovakia was the receiver of net transfers from the Czech Republic. However, the exact size of the transfer has never been officially reported. ${ }^{28}$ The available estimates of the size of the transfer in 1992 range from CSK 13.5 billion (Hajek et al., 1993) to CSK 25 billion (OECD, 1994), or 4.4 and $8 \%$ of Slovak GDP, respectively. Hajek et al. also estimate the net transfer for 1990 and 1991 at CSK 3.8 and 7.7 billion, or 1.5 and $2.6 \%$ of Slovak GDP, respectively. ${ }^{29}$ Moreover, additional transfers could have resulted from the fact that the prices were not determined by market clearing but rather were set centrally. ${ }^{30}$

Fiscal transfers were an important source of the equalization of per capita income within the former federation. In 1950 Slovak per capita NMP was 64\% of the Czech level while in 1989, it was already $88 \%$. The gap was much smaller as measured by disposable NMP; the corresponding figures are 81 and $92 \%$ and again highlight the importance of transfers.

These numbers suggest that fiscal transfers in the former Czechoslovakia served primarily the purpose of redistribution, not risk sharing, at least before the outset of economic reforms. This conclusion is supported by a comparison of the correlation coefficients estimated for NMP and disposable NMP (Table 1). While the estimates of the correlation of permanent shocks do not differ much for NMP

${ }^{27}$ The overall decline was $0.5 \%$. The other factors that they identify and their contributions were world recession $(-2.1 \%)$, inflow of FDI $(+2.7 \%)$, export growth $(+3.1 \%)$, restrictive fiscal policy $(-1.3 \%)$, and other factors $(-0.2 \%)$.

${ }^{28}$ In Czechoslovakia, the federal government collected most of the tax revenue and in turn redistributed it to the two republics. This makes any estimation of the extent of transfers a very complicated task.

${ }^{29}$ Krovak and Zamrazilova (1990) attempt to quantify the size of this transfer from 1950 to 1988. According to their estimates, the average transfer was some 14\% of Slovak disposable NMP during the 1950's and 1960's and 10\% during the 1970's and 1980's. However, their methodology significantly overestimates the size of the transfer. In particular, they disregard the effects of Czech-Slovak bilateral trade and the borrowing by the federal government, and attribute the lion's share of the contribution of Czechoslovak foreign trade to Czech NMP.

${ }^{30} \mathrm{We}$ are grateful to a referee for suggesting this point. 
and disposable NMP, the estimated correlation of temporary shocks is generally lower for disposable NMP, except for in the last sub-period. On the other hand, the figures estimated by Hajek et al. (1993) indicate a considerable increase in the size of the net transfer since the start of the transition. This response to the greater costs of reforms incurred by Slovakia suggests that risk sharing became more important after the collapse of the Communist regime. Nevertheless, the fact that the direction of fiscal transfers was consistently from the Czech Republic to Slovakia raises an important issue. If transfers are to serve effectively as insurance, they have to sum to zero in net present value over the long run. Otherwise, the insurance mechanism is not actuarially fair and the net payer has to reap additional economic or political benefits in order to find it attractive to remain in the union. ${ }^{31}$

The reasons for sustaining such a non-zero-sum arrangement were clearly political during the Communist period. Indeed, equalization of per capita incomes was part of the official policy of the Communist governments. On the other hand, sustaining the union became politically difficult after the collapse of Communism, as the Slovak political representation sought to reassert itself and pushed for increased autonomy. Indeed, the split of the federation removed an important source of political instability, which eventually benefited the Czech Republic as it facilitated its inclusion in the first group of candidates for EU enlargement, and entry to NATO. Slovakia, on the other hand, reverted to nationalism, corruption, and authoritarian policies, and thus excluded itself from the first round of accession negotiations with the EU as well as from NATO enlargement.

Given the non-zero-sum nature of the fiscal transfers, the breakup was economically more advantageous for the Czech Republic. Drèze (1993) proposes a procedure for dismantling unions in a way that is distributionally neutral. Accordingly, the net payer should pay an exit fee equal to the present value of future transfers to the other region at the time of the breakup. However, a different procedure was applied for breaking up Czechoslovakia. Essentially, the liabilities of the federal state were divided 2:1, according to the population ratio between the Czech Republic and Slovakia. Immovable assets were taken over by the country in which they were located, whereas other assets were typically divided according to the population ratio. Hence by seceding, the Czech Republic gained and Slovakia lost the value of the implicit liability to continue these fiscal transfers in the future.

Cessation of the transfers after the breakup of the political union essentially sealed the fate of the monetary union. In the absence of fiscal transfers, and with decreasing bilateral trade, continuing economic decline, and persisting unemployment differences between the two republics, monetary union would have been costly for Slovakia even in the short run. Therefore, expectations arose that

\footnotetext{
${ }^{31}$ We are grateful to a referee for suggesting this point.
} 
Slovakia would have to resort to monetary policy to counter the adverse economic developments. Indeed, in June 1993, the Slovak currency was devaluated by $10 \%$. Thus, the absence of fiscal transfers made the monetary union unstable and increased the need for exchange-rate adjustments, thus fueling speculations that eventually doomed the common currency.

\section{CONCLUSIONS}

In this paper, we address the question whether Czechoslovakia was an optimum currency area. We show that after four decades of integration and centralized economic policies under the Communist regime, the economies of the Czech Republic and Slovakia remained vulnerable to asymmetric shocks and illequipped to deal with the adverse effects of such shocks. The economic reforms, which started in the early 1990's, have had substantial and persistent asymmetric effects on the Czech and Slovak economies. Consequently, the Czech and Slovak Republics quickly diverged politically, with continuing high support for radical economic reforms in the Czech Republic contrasted with increasing opposition against the reforms in Slovakia. While the Slovaks pushed for an increased degree of political and economic autonomy, the Czechs became increasingly aware of the economic costs of sustaining the union. Clearly, the economic problems that affected Czechoslovakia were not insurmountable. Regional disparities could have been reduced by measures aimed at increasing labor mobility, by increased fiscal transfers, or by region-specific policies. However, the political commitment necessary to undertake such measures was lacking in 1992. Eventually, Czechoslovakia and subsequently the Czech-Slovak monetary union broke up despite the associated costs and amidst little political protest in either Czech lands or Slovakia.

The experience of the breakup of Czechoslovakia and the failure the monetary union between the Czech and Slovak republics can be used to draw lessons for other monetary unions and/or multi-national states. The economic developments that preceded the disintegration of Czechoslovakia appear similar to those that underlie the current secessionist tensions in Belgium, Italy, or Spain, or those that may trouble the EMU in the future. One way to interpret the disintegration of Czechoslovakia is to explain it as the result of the desire of the Slovak people for an independent nation state. Accordingly, Czechoslovakia was an artificial creation held together by the force of political repression of the Communist regime. Once the political constraints that were preventing it from disintegrating disappeared, Czechoslovakia broke up despite considerable economic, social, and demographic convergence, without regard for any economic rationale. Then, the lesson from the split of Czechoslovakia would be rather bleak for other unions as it would seem that nationalism may easily prevail over economics.

The results of our analysis, instead, indicate that economic factors were important for the breakup of Czechoslovakia. If the reasons for the breakup of 
Czechoslovakia were primarily political, there was little to gain from dissolving the monetary union. Therefore, given that the monetary union failed, there should have been economic reasons underlying its collapse, and, in turn, also the disintegration of Czechoslovakia. The low correlation of permanent shocks in the pre-reform period constituted a source of instability and pressure for exchange rate adjustments in the presence of a sufficiently large asymmetric shock. The economic reforms implemented after the collapse of communism brought about substantial asymmetric developments as evidenced by the large differences in unemployment rates. Labor mobility proved ineffective in mitigating these adverse effects. Fiscal transfers were insufficient to equilibrate the shocks and became increasingly politically costly over time. The asymmetric economic developments in turn engendered deepening political differences between the two republics (Jan Fidrmuc, 1999a). Eventually, Czechoslovakia broke up, and the Czech-Slovak monetary union was conceived as an a priori transitory arrangement. Since the Czech-Slovak monetary union had even fewer instruments to absorb the adverse effects of asymmetric shocks, it is no wonder that it collapsed within five weeks.

The breakup of Czechoslovakia illustrates the importance of the political commitment to integration. It shows that the political commitment can dissipate quickly in the wake of extraordinary asymmetric economic developments and in the absence of effective mechanisms for mitigating them. The experience of other countries that struggle with regional disparities, such as Belgium or Italy, appears consistent with this point. From this perspective, it is worrisome that the EMU was conceived without giving much consideration to the question of the economic costs and benefits of participation by individual countries. The EMU may be beneficial for the core countries, i.e., Germany, France, Austria, and the Benelux, but may prove costly for the countries whose economies are not so closely integrated with the core.

Moreover, the failure of the Czech-Slovak monetary union highlights the importance of the institutional design of a currency union. The design of the Czech-Slovak monetary union was fundamentally flawed. The union did not have a single monetary authority; instead, monetary policy was decided and coordinated by the Monetary Committee, which was composed of representatives of the two national central banks. Clearly, the national representatives were charged with pursuing the interests of their own country rather than those of the union. The implementation of policy decisions was also up to the national banks. From its conception, the union's sustainability was undermined by low credibility and the demonstrated lack of political commitment to sustain the common currency in the long or even medium term. The low credibility and the lack of political commitment, in turn, induced substantial speculative transactions, which brought the monetary union down in a matter of weeks.

Finally, the quick collapse of the Czech-Slovak monetary union shows that, while the formation of a monetary union is a tedious job taking many years, its 
dissolution can occur quickly and does not need to be very costly. The temptation to secede is higher if the expected exit cost, consisting of the decline of trade with the rest of the union members and the cost of independence, i.e., introducing new institutions and currency and enforcing borders, is small. The disintegration of Czechoslovakia caused a significant decline of trade between the new successor countries. However, much of this decline occurred due to the falling relative importance of the bilateral trade in the wake of the growth of trade with third countries. The trade lost in the bilateral relationship was quickly diverted elsewhere, in particular toward the European Union.

The ease with which the Czech Republic and Slovakia introduced new national currencies just five weeks after the demise of the political union proves that the technical costs of currency separation do not have to be high. The costs of disintegration depend crucially on the agreed procedure and especially on the political will to cooperate and minimize the costs. Given that the successor states retained the customs union and the free movement of labor, the costs of both the breakup of Czechoslovakia and the dissolution of the monetary union were relatively low, even in the short run and, thus, failed to serve as a deterrent to further disintegration. Thus, the concerns that the costs of dissolving the monetary union in Europe would necessarily be high do not seem to us to be warranted. Hence, depending on circumstances, dissolution of the EMU or secession by some of its members can be swift and without prohibitively high costs.

\section{REFERENCES}

Abraham, Filip, Buyst, Erik, and Geyssens, Sven, "Trade Integration in the Twentieth Century: What Does Belgian History Tell Us?” Weltwirtsch. Arch. 133, 4:708-735, 1997.

Bauer, Thomas, and Zimmermann, Klaus, F., "Modeling International Migration: Economic and Econometric Issues." In Rob van der Erf and Liesbeth Heering, Eds., Causes of International Migration. Proceedings of a Workshop, Luxembourg, 14-16 December 1994, pp. 95-115. Luxembourg: Office for Official Publications of the European Communities, 1995.

Batt, Judy, "Czecho-Slovakia in Transition: From Federation to Separation." RIIA Discussion Paper 46. London: The Royal Institute of International Affairs, 1993.

Bayoumi, Tamim, and Eichengreen, Barry, "Shocking Aspects of European Monetary Integration." In Francisco Torres and Francesco Giavazzi, Eds., Adjustment and Growth in the European Monetary Union, pp. 193-229. Cambridge, UK: Cambridge University Press and CEPR, 1993.

Bernard, Andrew B., and Durlauf, Steven N., "Convergence of International Output Movements." NBER Working Paper 3717. Cambridge, MA: National Bureau of Economic Research, 1991.

Capek, Ales, and Sazama, Gerald, W., "Czech and Slovak Economic Relations." Europe-Asia Stud. 45, 2:211-235, 1993.

Cheikbossian, Guillaume, "Seigniorage, Delegation and Common Currency." DELTA Document 95-34. Paris: DELTA (Joint Research Unit CNRS-EHESS-ENS), 1995.

Cheikbossian, Guillaume, and Maurel, Mathilde, "The New Geography of Eastern European Trade." Kyklos 51, 1:45-71, 1998.

Cohen, Benjamin, "Beyond EMU: The Problem of Sustainability." Econ. Politics 5, 2:187-203, July 1993. 
Dedek, Oldrich, Ed., The Breakup of Czechoslovakia: An In-Depth Economic Analysis. Aldershot, UK: Avebury, 1996.

Dornbusch, Rudiger, "Monetary Policy of Post-Communism: Lessons from the End of the AustroHungarian Empire." Weltwirsch. Arch. 128, 3:391-424, 1992.

Drèze, Jacques, "Regions of Europe: A Feasible Status, to Be Discussed." Econ. Policy Europ. Forum 8, 17:265-287, Oct. 1993.

Eichengreen, Barry, "Labor Markets and European Monetary Unification.” In Paul R. Masson and Mark P. Taylor, Eds., Policy Issues in the Operation of Currency Unions, pp. 130-162. Cambridge, UK: Cambridge University Press, 1993.

Eichengreen, Barry, "European Monetary Unification: A Tour d'Horizon." Oxford Rev. Econ. Policy 14, 3:24-40, Autumn 1998.

Estrin, Saul, and Urga, Giovanni, "Convergence in Output in Transition Economies: Central and Eastern Europe, 1970-95.” Centre for Economic Policy Research Discussion Paper 1616. London, Apr. 1997.

Fidrmuc, Jan, "Political Support for Reforms: Economics of Voting in Transition Countries." Europ. Econ. Rev. forthcoming, 1999a.

Fidrmuc, Jan, "Stochastic Shocks and Incentives for (Dis)Integration." CEPR Discussion Paper 2104. London: Centre for Economic Policy Research, March 1999b.

Fidrmuc, Jan, and Fidrmuc, Jarko, "Impediments to Exports in Slovakia." In Richard Cooper and János Gács, Eds., Trade Growth in Transition Economies, pp. 189-226. Cheltenham, UK: Edward Elgar, 1997.

Fidrmuc, Jarko, "Ethnic Minorities and Regional Unemployment." In Stephano Scarpetta and Andreas Wörgötter, Eds., The Regional Dimension of Unemployment in Transition Countries, pp. 382-416. Paris: Organisation for Economic Co-operation and Development, 1995.

Fidrmuc, Jarko, “Trade Diversion in 'Left-Outs' in Eastward Enlargement of European Union: The Case of Slovakia." Europe-Asia Stud. 51(4), forthcoming, 1999.

Frankel, Jeffrey A., and Rose, Andrew K., "The Endogeneity of the Optimum Currency Area Criteria." Econ. J. 108, 449:1009-1025, July 1998.

Funke, Michael, "The Nature of Shocks in Europe and Germany." Economica 64, 255:461-469, Aug. 1997.

Garber, Peter M., and Spencer, Michael G., "The Dissolution of the Austro-Hungarian Empire: Lessons for Currency Reform." Essays in International Finance, No. 191. Princeton, NJ: Princeton University, Department of Economics, International Finance Sector, Feb. 1994.

Goodhart, Charles A. E., "The Political Economy of Monetary Union." In Peter B. Kenen, Ed., Understanding Interdependence. The Macroeconomics of the Open Economy, pp. 448-505. Princeton, NJ: Princeton University Press, 1995.

Hajek, M., et al., "Ceskoslovenska ekonomika v zaveru roku 1992.” Czech National Bank Research Paper 3. Prague: Czech National Bank, 1993.

Hamilton, Carl B., and Winters, Alan L., "Opening up International Trade with Eastern Europe." Econ. Policy A Europ. Forum 0, 14:77-114, Apr. 1992.

Kenen, Peter B., "The Theory of Optimum Currency Areas: An Eclectic View." In Mundell and Swoboda, Eds., Monetary Problems of the International Economy. Chicago: University of Chicago Press, 1969.

Kiss, Yudit, "Lost Illusions? Defense Industry Conversion in Czechoslovakia: 1989-92." EuropeAsia Stud. 45, 6:1045-1069, 1993.

Korbel, Josef, Twentieth-Century Czechoslovakia: The Meaning of its History. New York: Columbia University Press, 1977.

Krovak, Jiri, and Zamrazilova, Eva, "Analyza presunu národniho duchodu mezi republikami." Politicka Ekonomie 38, 963-970, 1990.

Krugman, Paul, "Lessons of Massachusetts for EMU." In Francisco Torres and Francesco Giavazzi, 
Eds., Adjustment and Growth in the European Monetary Union, pp. 241-261. Cambridge, UK: Cambridge University Press and CEPR, 1993.

Linnemann, Hans, An Econometric Study of International Trade Flows. Amsterdam: North-Holland, 1966.

Machlup, Fritz, A History of Thought on Economic Integration. New York: Columbia University Press, 1977.

McKinnon, Ronald I., “Optimum Currency Areas.” Amer. Econ. Rev. 53, 717-725, Sept. 1963.

Melitz, Jacques, "The Current Impasse in Research on Optimum Currency Areas." Europ. Econ. Rev. 39, 3-4: 492-500, Apr. 1995.

Minford, Patrick, "Discussion of Bayoumi and Eichengreen." In Francisco Torres and Francesco Giavazzi, Eds., Adjustment and Growth in the European Monetary Union, pp. 235-240. Cambridge, UK: Cambridge University Press and CEPR, 1993.

Mundell, Robert A., "A Theory of Optimum Currency Areas.” Amer. Econ. Rev. 51, 657-665, Sept. 1961.

Organization for Economic Co-operation and Development, Economic Survey of the Czech and Slovak Republics. Paris: OECD, 1994.

Pavlinek, Petr, "Regional Development and the Disintegration of Czechoslovakia." Geoforum 26, 4:351-372, 1995.

Prokop, L., "Priprava a prubeh menove odluky v Ceske republice v r. 1993." Czech National Bank Research Paper 28, Prague: Czech National Bank, 1994.

Rose, Richard, "Czechs and Slovaks Compared: A Survey of Economic and Political Behaviour." Studies in Public Policy, No. 198. Glasgow, Scotland: Centre for the Study of Public Policy, University of Strathclyde, 1992.

Smidkova, Katerina, "Exchange-Rate System between the Czech and Slovak Republics." Czech National Bank Research Paper 16, Prague: Czech National Bank, 1994.

Stranger, Allison K., "Czechoslovakia's Dissolution as an Unintended Consequence of the Velvet Constitutional Revolution.” East Europ. Constitutional Rev. 5, 4:40-46, Fall 1996. [New York/Budapest: New York University School of Law and Central European University]

Sujan, Ivan, and Sujanova, Milota, "The Macroeconomic Situation in the Czech Republic." CERGE-EI Working Paper 46. Prague: Charles University, Center for Economic Research and Graduate Education, 1994.

Todaro, Michael P., "A Model of Labor Migration and Urban Unemployment in Less Developed Countries." Amer. Econ. Rev. 59, 1:138-148, 1969.

Von Hagen, Jürgen, "Fiscal Policy and Intranational Risk-sharing." ZEI Working Paper B13. Bonn: Center for European Integration Studies (ZEI), University of Bonn, 1998.

Wolchik, Sharon, L., "The Politics of Transition and the Breakup of Czechoslovakia." In Jiri Musil, Ed., The End of Czechoslovakia, pp. 225-244. Budapest: Central European University Press, 1995. 